\title{
PENGARUH Aspergillus niger PADA PEMBUATAN BIOETANOL DARI LIMBAH KULIT UBI KAYU DAN KULIT NANAS
}

\author{
Henny Juniar*1), Ummi Kalsum ${ }^{1)}$ \\ 1)Prodi Teknik Kimia Fakultas Teknik Universitas Muhammadiyah Palembang \\ *email :henijuniar02@gmail.com
}

\begin{abstract}
Abstrak
Bioetanol merupakan salah satu bahan bakar terbarukan yang saat ini sudah dimanfaatkan diberbagai Negara termasuk Indonesia. Sumatera Selatan terkenal memiliki kekayaan alam yang melimpah yang dapat digunakan sebagai bioenergy alternative, hal ini didukung dengan produksi buah-buahan dan umbi-umbian di Sumatera Selatan khususnya buah nanas. Dalam pembuatan bioetanol dari limbah nanas dan ubi kayu menggunakan fermentasi (Aspergillus niger),dan proses distilasi untuk pemurnian. Hasil penelitian menunjukan bioetanol campuran kulit nanas dan ubi kayu sebesar $10 \mathrm{ml}$ dengan kadar bioetanol 3,27 \% lebih banyak dibandingkan dari bioetanol masing masing limbah nanas dan ubi kayu yang diperoleh dengan kadar etanol yang lebih tinggi dari pada hasil masingmasing limbah kulit ubi kayu dan limbah kulit nanas yaitu sebesar 7,17 ml.
\end{abstract}

Kata Kunci : aspergillus niger, bioetanol, kulit ubi kayu, kulit nanas

\section{PENDAHULUAN}

Krisis bahan bakar minyak bumi tahun terakhir ini mengalami peningkatan, tidak hanya pada Negaranegara maju saja, tetapi juga di negara berkembang termasuk Indonesia. Untuk mengatasi krisis bahan bakar minyak perlu dikembangkan sumber energy yang baru dan terbarukan sekaligus ramah lingkungan. Menurut keputusan Menteri ESDM Nomor 32 Tahun 2008 'Bioetanol (E100) adalah produk etanol yang dihasilkan dari bahan baku hayati dan biomasa lainnya yang diproses secara bioteknologi dan wajib memenuhi standar mutu (spesifikasi) sesuai dengan ketentuan peraturan perundang-undangan jika ingin digunakan sebagai bahan bakar alternative". Sumatera Selatan terkenal memiliki kekayaan alam yang melimpah yang dapat digunakan sebagai bioenergy alternative, hal ini didukung dengan produksi Buah-buahan dan umbi-umbian di Sumatera Selatan khususnya buah nanas. Buah nanas saat ini memiliki perkebunan berdasarkan Badan Statistik Indonesia Tahun 2017 mencapai 495 ha dengan total produksinya 57.990 ton/tahun. Selain itu pertumbuhan umbi-umbian khususnya ubi kayu mencapai luas lahan $275 \mathrm{Ha}$ dengan jumlah produksi 1.852 ton/tahun. Sebagai Negara agraris dan tropis, Indonesia telah dianugerahi kekayaan alam yang melimpah yang dapat dijadikan sebagai bioenergi. Sesuai dengan Peraturan Pemerintah No.5/2006, kurun waktu 2015-2020, pemerintah menargetkan menganti 1,48 miliar liter bensin dengan bioetanol. Diperkirakan kebutuhan akan meningkat 15\% pada tahun 2016-2025. Saat ini bioetanol baru dapat dipasok sebanyaj 137.000 liter setiap bulannya $(0,4 \%)$. Hal ini berarti setiap bulan Pemrintah kekurangan pasokan 30.696.000 liter bioetanol sebagai bahan bakar (Nurianti, 2012). Dengan semakin meningkatnya produksi nanas dan ubi kayu maka limbah yang dihasilkan akan semakin 
meningkat. Pemanfaatan sampah kulit nanas dan limbah ubi kayu hanya digunakan sebagai pakan ternak. Untuk menambah nilai ekonomis sampah kulit nanas dan kulit ubi kayu , maka dapat dimanfaatkan sebagai bahan baku pembuatan etanol dengan cara hidrolisa dan fermentasi dengan menambahan beberapa variabel yeast (Aspergillus niger), serta pemurnian dengan distilasi.

\section{METODELOGI PENELITIAN}

\section{Bahan dan alat yang digunakan dalam penelitian :}

Yeast (ragi) Saccharomycescerevisiae, kulit ubi kayu, kulit nanas, akuades, medium PDA. Perlengkapan 1 set destilasi, blender, saringan, gelas beker,tabung reaksi, rak tabung reaksi, cawan petri, jarum ose, bunsen burner, erlenmeyer, timbangan analitik, $\mathrm{pH}$ meter, stopwatch, kompor listrik, termometer, piknometer, pengaduk, pisau. Kombinasi perlakuan yang diperoleh adalah sebagai berikut:

$\mathrm{U} 0=$ tanpa limbah kulit ubi kayu

$\mathrm{K} 0=$ tanpa limbah kulit nanas

U1 = limbah kulit ubi kayu 200 gram

$\mathrm{K} 1$ = limbah kulit nanas 200

gram $\mathrm{U} 2=$ limbah kulit ubi kayu 300 gram

$\mathrm{K} 2$ = limbah kulit nanas 300

gram U3 = limbah kulit ubi kayu 400 gram

$\mathrm{K} 3$ = limbah kulit nanas 400

\section{gram Prosedur Penelitian :}

Kulit nanas dan kulit ubi kayu dipotong kecil-kecil, di cuci bersih, diblender dan kemudian disaring untuk mendapatkan pati dari kulit nanas dan kulit ubi kayu. Dimasukan ke dalam Erlenmeyer ukuran $2000 \mathrm{ml}$, ditamabah air kemudian dipanaskan dengan temperature $1000^{\circ} \mathrm{C}$ sselama $1 / 4 \mathrm{jam}$. Dinginkan selama 1 jam, masukan dalam wadah untuk proses sakarifikasi, masukan aspergillus niger sebanyak $10 \%$ dari larutan total, untuk menguraikan bubur pati kulit nanas dan ubi kayu, kemudian di diamkan selama 2 jam. Selanjutnya difermentasi dengan penambahan Saccharomyces cerevisiae, lalu ditutup rapat, dengan suhu $30-32{ }^{\circ} \mathrm{C}$ dan $\mathrm{pH}$ 4,7- 5,5. Setelah proses fermentasi 7 hari, terdapat 3 lapisan endapan protein bawah sedangkan bagian atas air dan alcohol. Kemudian disaring yang memisahkan endapan protein, etanol yang bercampur dengan air, di distilasi dengan suhu $70^{\circ} \mathrm{C}$ atau sesuai dengan titik didih etanol, selanjutnya hasil distilasi dianalisa untuk menentukan kadar etanol.

\section{HASIL PENELITIAN DAN PEMBAHASAN}

\section{Pengaruh nilai pH Terhadap Hasil Bioetanol dari Campuran Kulit Nanas dan Ubi Kayu}

Derajat keasaman $(\mathrm{pH})$ atau alkalinitas adalah suatu larutan, dimana nilai $\mathrm{pH}$ ini sangat penting dalam pertumbuhan mikroorganisme, karena kadar $\mathrm{pH}$ sangat mempengaruhi kinerja enzim. Kadar $\mathrm{pH}$ diawal penelitian limbah nanas rata-rata nilai $\mathrm{pH} 4,7$ dan nilai limbah ubi kayu kadar $\mathrm{pH}$ ratarata 6,2. Dengan nilai pH rata-rata 4,7 dan 6,2 akan menunjukan aspergillus niger akan bekerja dengan baik. Menurut Keenam et al,(1990), Pertumbuhan mikroorganisme pada proses fermentasi akan terjadi perubahan $\mathrm{pH}$ asam atau basah. 
Tabel 1. Nilai pH pada awal pembuatan Biotanol dari Kulit Nanas dan Ubi Kayu

\begin{tabular}{|c|c|c|c|c|}
\hline \multirow{2}{*}{$\begin{array}{c}\text { Limbah Kulit } \\
\text { nanas }\end{array}$} & & \multicolumn{2}{|c|}{ Limbah kulit ubi kayu } & \\
\cline { 2 - 5 } & U0 & U1 & U2 & U3 \\
\hline K0 & 0,0 & 6,0 & 6,5 & 6,2 \\
\hline K1 & 4,7 & 5,0 & 5,7 & 5,8 \\
\hline K2 & 4,7 & 5,5 & 5,7 & 5,8 \\
\hline K3 & 4,7 & 5,5 & 5,8 & 5,2 \\
\hline
\end{tabular}

Tabel 2. Nilai pH pada Akhir Pembuatan etanol

\begin{tabular}{|c|c|c|c|c|}
\hline \multirow{2}{*}{$\begin{array}{c}\text { Limbah Kulit } \\
\text { nanas }\end{array}$} & & \multicolumn{2}{|c|}{ Limbah kulit ubi kayu } & \\
\cline { 2 - 5 } & $\mathrm{U} 0$ & $\mathrm{U} 1$ & $\mathrm{U} 2$ & $\mathrm{U} 3$ \\
\hline $\mathrm{K} 0$ & 0,0 & 3,2 & 3,1 & 3,2 \\
\hline K1 & 4,5 & 3,3 & 3,2 & 3,3 \\
\hline K2 & 4,5 & 3,2 & 3,3 & 3,1 \\
\hline K3 & 4,4 & 3,4 & 3,3 & 3,2 \\
\hline
\end{tabular}

Kecenderungan media fermentasi semakin asam disebabkan amonia yang digunakan sel khamir sebagai sumber nitrogen diubah menjadi $\mathrm{NH}^{+}$. Molekul $\mathrm{NH}_{4}{ }^{+}$akan menggabungkan diri ke dalam sel sebagai R-NH3. Dalam proses ini $\mathrm{H}^{+}$ditinggalkan dalam media, sehingga semakin lama waktu fermentasi semakinrendah pH media (Judoamidjojo dkk, 1989). Menurut Yasmeen et al., (2002), Aspergillus Niger memiliki pH optimum untuk pertumbuhan 4,0-6,0, sehingga penurunan $\mathrm{pH}$ sangat berpengaruh terhadap pertumbuhan Aspergillus niger. Cendawan ini menghasilkan enzim $\alpha$-amilase dan glukoamilase yang berperan mengurai pati menjadi glukosa karbohidrat yang lebih sederhana. Setelah menjadi gula difermentasi menjadi etanol. Menurut Stewart (1984), enzim $\alpha$-amilase mampu memutuskan ikatan $\alpha-1,4$ secara acak di bagian dalam dari pati, baik dalam amilosa maupun amilopektin. Akibat dari aktivitas tersebut rantai pati terputus-putus menjadi maltosa, maltotriosa, glukosa dan dekstrin. Sedangkan enzim glukoamilase akan memecah ikatan $\alpha-1,4$ maupun $\alpha-1,6$ glikosida pada molekul pati menjadi gulareduksi. Menurut Berka et al., (1992), enzim $\alpha$-amilase dan glukoamilase bekerja efektif pada kondisi pati cair. Menurut Fessenden dan Fessenden (1997), Aspergillus niger mengubah bahan yang mengandung pati menjadi alkohol. Dalam proses sakarifikasi (pemecahan gula kompleks menjadi gulasederhana) Aspergillus niger ini bekerja selama 2 jam karena setelah 2 jam dilakukan proses fermentasi menggunakan ragi. Menurut Schegel (1994),produsen utama alkohol adalah ragi terutama Saccharomyces cerevisiae, yangmeragikan karbohidrat menjadi etanol dan $\mathrm{CO} 2$. Peragian glukosa oleh ragimerupakan peristiwa anaerob. Pada kondisi anaerob terjadi penimbunan alkoholatau etanol. Saccharomyces cerevisiae sendiri merupakan jenis khamir fakultatif anaerob.

\section{Pengaruh Aspergillus Niger terhadap nilai Etanol dari Kulit Nanas dan Ubi Kayu}

Pada pembuatan alkohol dengan cara fermentasi biasanya dengan bantuan mikroorganisme. Bahan dasar yang dapat dipakai untuk membuat alkohol dengan cara fermentasi merupakan bahan yang mengandung pati (karbohidrat) menjadi glukosa. Aspergillus niger mengubah bahan yangmengandung pati menjadi glukosa, selanjutnya Saccharomyces cerevisiae akan mengubah glukosa menjadi alkohol. Untuk memisahkan alkohol dan air dapat dilakukan penyulingan atau 
destilasi sehingga dapat diperoleh alkohol dengankadar kurang lebih 90\% (Fessenden dan Fessenden, 1999). Hasil penelitian bietanol dari proses fermentasi dilanjutkan destilasi dengan menggunakan campuran limbah kulit ubi kayu dan limbah kulit nanas dengan menggunakan Aspergillus niger, diperoleh hasil sebagai berikut :

Tabel 3. Hasil Bioetanol Campuran Limbah ubi kayu dan Limbah Kulit Nanas

\begin{tabular}{|c|c|c|c|c|c|}
\hline \multirow{2}{*}{$\begin{array}{c}\text { Limbah Kulit } \\
\text { nanas }\end{array}$} & & \multicolumn{2}{|c|}{ Limbah kulit ubi kayu } & & \multirow[t]{2}{*}{ Rerata } \\
\hline & U0 & $\mathrm{U} 1$ & U2 & U3 & \\
\hline K1 & 0,0 & 5,8 & 6,8 & 5,9 & 4,62 \\
\hline K2 & 2.1 & 6,5 & 7,8 & 6,5 & 5,72 \\
\hline K3 & 4,1 & 8,0 & 8,2 & 8,4 & 7,17 \\
\hline K4 & 5,4 & 6,9 & 7,9 & 8,2 & 7,1 \\
\hline Rerata & 2,9 & 6,8 & 7,67 & 7,25 & 6,15 \\
\hline
\end{tabular}

Berdasarkan Tabel 3. terlihat bahwa campuran limbah kulit ubi kayu dan limbah kulit nanas menghasilkan etanol yang lebih tinggi dari pada hasil masing-masing limbah kulit ubi kayu dan limbah kulit nanas yaitu sebesar 7,17 ml. Menurut penelitian Maretni (2006), pertumbuhan khamir juga dapat dipengaruhi oleh beberapa faktor. Faktor yang mempengaruhi diantaranya adalah formulasi media yang digunakan sebagai proses pengembangbiakan mikroba sejak persiapan inokulum sampai tahap fermentasi akan didapatkan hasil yang optimum ketika pertumbuhan enzim maksimum dan ketersediaan substrat cukup. Faktor keberhasilan fermentasi sangat dipengaruhi oleh interaksi antarsubstrat dengan mikroba. Mikroba membutuhkan energi yang berasal dari karbohidrat, protein, lemak, mineral, dan zat lain yang terdapat di dalam substrat. Sehingga mikroba harus mampu tumbuh pada substrat dan mudah beradaptasi dengan lingkungan. Selain itu mikroba juga mampu mengeluarkan enzim pentingyang dapat melakukan perubahan yang dikehendaki secara kimia (Bioindustri,2008). Menurut Desrosier (1987), kecepatan reaksi dalam suatu proses kimia maupun reaksi yang ditolong oleh enzim tidaklah konstan.

\section{KESIMPULAN}

Hasil bioetanol campuran kulit nanas dan ubi kayu sebesar $10 \mathrm{ml}$ dengan kadar bioetanol 3,27 \% lebih banyak dibandingkan dari bioetanol masing masing limbah nanas dan ubi kayu dengan hasil campuran limbah kulit ubi kayu dan limbah kulit nanas diperoleh kadar etanol yang lebih tinggi dari pada hasil masing-masing limbah kulit ubi kayu dan limbah kulit nanas yaitu sebesar 7,17 ml.

\section{DAFTAR PUSTAKA}

Berka, R. M., D. Nigel., and W. Michael. 1992. Industrial enzymes from Aspergillus Species. New York : Butterwoth-

Bioindustri. 2008. Produksi Protein Sel Tunggal Hasil Proses fermentasi Kulit Ubi Kayu. http :// Bioindustri. Blogspot. com [15 Januari 2021 ].

Desrosier, N. W. 1987. Teknologi Pengawetan Pangan. Jakarta : Universitas Indonesia Press

Fessenden, R dan J. Fessenden.1997. Kimia Organik Jilid 1. Jakarta : Erlangga. Fessenden, R dan J. Fessenden. 1999. Kimia Organik Jilid 2. Jakarta : Erlangga.

Judoamidjojo, M., Darwis dan Sa'id. 1989. Teknologi Fermentasi. Jakarta : Rajawali.

Keenan, C. W., D. Kleinfelter, dan J. Wood. 1990. Kimia Untuk Universitas. Jakarta : Erlangga. Nurianti, Y. 2007. Pasok Langsung ke Pertamina. http://www.trubus-online.com [13 Januari 2021]. 
Maretni, T. 2006. Perbandingan Kadar Glukosa dan Alkohol Hasil Fermentasi Umbi Talas (Xanthosoma violaceum schott). Skripsi. Jurusan Biologi Fakultas Keguruan dan Ilmu Pendidikan. Surakarta : Universitas Muhammadiyah Surakarta.

Schlegel, H.G. 1994. Mikrobiologi Umum. Yogyakarta : Universitas Gadjah Mada.

Steward, G. G. 1984. Biology of Ethanol Producing Microorganism. Critical Review Bioethanol.

Yasmeen, A., Shahid, R., Latif, F., and Rajoka, M.I. 2002. Ethanol Production from Raw Corn Strach by Saccharification with Glucoamylase from Aspergillus niger Mutant M115 and Fermentation with Saccharomyces cerevisiae. Simposium. Pakistan: National Institute for Biotechnology and genetic Engineering. 